\title{
Effect of Rate and Sources of Nitrogen, Phosphorus and Zinc Fertilization on Potassium Nutrition of Rice in Different Cultivation Methods
}

\author{
Amit Anil Shahane and Yashbir Singh Shivay*
}

Division of Agronomy, ICAR-Indian Agricultural Research Institute, New Delhi (110 012), India

\section{Corresponding Author}

Yashbir Singh Shivay

e-mail: ysshivay@hotmail.com

\author{
Article History \\ Article ID: AR1881 \\ Received in 09 ${ }^{\text {th }}$ July, 2018 \\ Received in revised form $19^{\text {th }}$ July, 2018 \\ Accepted in final form 02 ${ }^{\text {nd }}$ August, 2018
}

\begin{abstract}
A field study was conducted in 2013-14 and 2014-15 at Research Farm of ICAR-Indian Agricultural Research Institute, New Delhi, India with the objective to quantify variation in concentration and uptake of potassium (K) as influenced by rate and sources of nitrogen (N), phosphorus $(\mathrm{P})$ and zinc $(\mathrm{Zn})$ in rice. The rate of nutrient application ( $\mathrm{N}$ and $\mathrm{P}$ ) had strongly significant effect, followed by cultivation methods and least in case of $\mathrm{Zn}$ fertilization on concentration and uptake of $\mathrm{K}$ in rice. Among concentration and uptake, uptake was more affected due to applied treatments; while among growth stages, effect was significant at 70 and 100 days after sowing and in straw and milled rice. Application of recommended dose of $\mathrm{N}$ and $\mathrm{P}$ (RDN) increased total K uptake by 10-12 and $27-28 \mathrm{~kg}^{-1}$ over $75 \%$ RDN and control, respectively. Increase in total $\mathrm{K}$ uptake in puddled transplanted rice (PTR) and system of rice intensification (SRI) was 11-13 and $12-13 \mathrm{~kg}$ $\mathrm{ha}^{-1}$ over aerobic rice system (ARS). Similarly, increase in uptake due to application of microbial inoculations (MI) and $\mathrm{Zn}$ fertilization was 8-14 and 3-7 kg ha-1. Soil available $\mathrm{K}$ showed negative balance which indicates that higher uptake than $\mathrm{K}$ applied through fertilizer and need of $\mathrm{K}$ fertilization in rice. Our study designates superiority of SRI and PTR among cultivation methods and RDN+Zn and $75 \% \mathrm{RDN}+\mathrm{MI}+\mathrm{Zn}$ within nutrient management options in $\mathrm{K}$ nutrition of rice.
\end{abstract}

Keywords: Aerobic rice system, microbial inoculation, potassium, rice

\section{Introduction}

Rice is staple food of India consuming $29.3 \%$ of the total fertilizer consumption in India, out of which share of potassium (K) is 3.64\% (0.9 mt) (FAl, 2016); while Prasad (2012) reported that share of rice in total fertilizer consumption in India was $37 \%$. In India, $\mathrm{K}$ fertilization is not getting much attention which can be justified from wide nutrient application ratio (6.7: 2.7: $1, \mathrm{~N}: \mathrm{P}_{2} \mathrm{O}_{5}: \mathrm{K}_{2} \mathrm{O}$ ) (Anonymous, 2017), disparity in $\mathrm{K}$ application rate and its total uptake in rice ( $30 \mathrm{~kg} \mathrm{~K}_{2} \mathrm{O} \mathrm{t}^{-1}$ grain produced), wheat ( $33 \mathrm{~kg} \mathrm{~K}_{2} \mathrm{O} \mathrm{t}^{-1}$ grain produced) or other cereals $(32.8 \mathrm{~kg}$ $\mathrm{K}_{2} \mathrm{O} \mathrm{t}^{-1}$ maize grain produced) (Tandon, 2013) and share of $\mathrm{K}$ in total fertilizer used in India (9.6\%) (Anonymous, 2017). The negative balance of $\mathrm{K}$ in soil was mentioned by Gurav et al. (2018) and Zhang et al. (2010), which also showed the need of $\mathrm{K}$ fertilization in rice. Singh et al. (2004) also emphasizes the importance of $\mathrm{K}$ nutrition in rice and wheat; while Yadav et al. (2000) reported the low rate of K application in ricewheat cropping system in Indo-Gangetic plains. Growth and yield ability of rice is influenced more strongly by nitrogen (N) followed by phosphorus (P). The strong effect of these two nutrients may overshadow the influence of $K$ on yielding ability. As both $\mathrm{N}$ and $\mathrm{P}$ have strong effect on growth, it may affect concentration and uptake of $\mathrm{K}$ in rice at different growth stages even after application of same rate of $\mathrm{K}$ application. At the same time, changes in cultivation method also had its own influence on soil $\mathrm{K}$ availability and plant $\mathrm{K}$ uptake. The increase in awareness among scientists, policy makers and stakeholders (farmers) about wastages of resource in puddled transplanted rice cultivation, new methods such as system of rice intensification (SRI) and aerobic rice system (ARS) getting more attention and importance. In such conditions, studying theses methods for their effect on $\mathrm{K}$ nutrition of rice and soil available $K$ status generate valuable scientific information. The influence of zinc ( $\mathrm{Zn}$ ) fertilization on dry matter production and yield (Syed et al., 2016; Shivay et al., 2015; Singh and Shivay, 2014) of rice was highlighted in various studies. This response of $\mathrm{Zn}$ fertilization may affect $\mathrm{K}$ status of rice. With this background a field study was planned with objective to study the effect of three different rates of $\mathrm{N}$ and $\mathrm{P}$ fertilizer $(0,75 \%$ and $100 \%$ recommended dose of $N$ and $P(R D N))$ (120 kg N ha-1 and $25.8 \mathrm{~kg} \mathrm{P} \mathrm{ha}^{-1}$ ), two different sources on $\mathrm{N}$ and $\mathrm{P}$ (fertilizers and microbial inoculations (MI) and $\mathrm{Zn}$ fertilization on $\mathrm{K}$ content in rice plant and soil in three rice 
cultivation methods.

\section{Materials and Methods}

A field experiment was conducted in rainy seasons of 2013-14 and 2014-15 at the Research Farm of ICAR-Indian Agricultural Research Institute, New Delhi. This farm is situated at a latitude of $28^{\circ} 38^{\prime} \mathrm{N}$, longitude of $77^{\circ} 10^{\prime} \mathrm{E}$ and altitude of $228.6 \mathrm{~m}$ above the mean sea level (Arabian Sea). The climate of Delhi is of sub-tropical and semi-arid type with hot and dry summer and cold winter and falls under the agro-climatic zone 'TransGangetic plains'. Total rainfall received in first and second year during rice growing season was $1,349.8 \mathrm{~mm}$ and $451.4 \mathrm{~mm}$; while evaporation losses during first and second rice growing seasons were $806 \mathrm{~mm}$ and $1075.1 \mathrm{~mm}$, respectively. The soil of experimental field was sandy clay loam in texture having $\mathrm{pH} 7.6$, organic carbon 0.54\% (Walkley and Black, 1934) and available N (Subbiah and Asija, 1956), P (Olsen et al., 1954), K (Hanway and Heidel, 1952) and DTPA-extractable Zn (Lindsay and Norvell, 1978) of $257 \mathrm{~kg} \mathrm{ha}^{-1}, 17 \mathrm{~kg} \mathrm{ha}^{-1}, 327 \mathrm{~kg} \mathrm{ha}^{-1}$ and $0.85 \mathrm{mg} \mathrm{kg}^{-1}$, respectively.

The experiment involving rice variety Pusa Sugandh 5 was conducted in split-plot design comprised of three main plots as methods of rice cultivation viz., puddled transplanted rice (PTR), system of rice intensification (SRI) and aerobic rice system (ARS) with nine nutrient management options as sub-plot treatments. Sub-plot treatments consisted of four treatments viz. RDN $\left(\mathrm{N}_{120} \mathrm{P}_{25.8}\right), 75 \% \mathrm{RDN}, 75 \% \mathrm{RDN}+$ Anabaena sp. (CR1)+Providencia sp. (PR3) consortia (MI1) and 75\% $\mathrm{RDN}+$ Anabaena-Pseudomonas biofilmed formulations (MI2) with and without $\mathrm{Zn}$ which making total eight treatments and another one treatment was absolute control $\left(\mathrm{N}_{0} \mathrm{P}_{0} \mathrm{Zn}_{0}\right)$. Potassium (K) was applied uniformly at the rate of $49.8 \mathrm{~kg} \mathrm{~K}$ $\mathrm{ha}^{-1}$ as basal dose. In case of $\mathrm{Zn}$, soil application of $5 \mathrm{~kg} \mathrm{Zn} \mathrm{ha}{ }^{-1}$ through $\mathrm{Zn}$ sulphate heptahydrate was applied in both rice crops at sowing/transplanting. Nitrogen was split applied in all treatments irrespective of dose at sowing, 30 days after sowing (DAS) and 60 DAS in ARS and 5 days after transplanting (DAT), 25 DAT and 55 DAT in both PTR and SRI. Sowing of rice in main field for ARS and sowing rice in nursery for transplanting in both PTR and SRI was done on same date. For ARS, direct sowing of seed (seed rate $60 \mathrm{~kg} \mathrm{ha}^{-1}$ ) was done with spacing of $20 \mathrm{~cm}$ between two rows using seed-drill. In SRI, 1 healthy seeding of 14 days old were transplanted hill ${ }^{-1}$ at a spacing of $20 \times 20 \mathrm{~cm}^{2}$, whereas in PTR, 2 healthy seeding of 25 days old, were transplanted per hill at a spacing of $20 \times 15 \mathrm{~cm}^{2}$. For application of microbial inoculants (MI), a thick paste of respective culture was made and applied to rice seedling in PTR and SRI method of rice cultivation by dipping roots in paste of respective culture for half an hour before transplanting. In ARS, pre-soaked seeds were treated with thick paste of culture made in carboxyl methyl cellulose. Standard recommended practices were followed for weed and water management in all three cultivation methods.

For measurement of above-ground shoot dry matter, representative plant sample were air dried and further dried in a hot air oven at $60^{\circ} \pm 2{ }^{\circ} \mathrm{C}$ till constant weight was obtained and expressed in $\mathrm{g} \mathrm{m}^{-2}$. After recording of dry matter accumulation, same samples were used to determine potassium concentration in plant; while for determination of $\mathrm{K}$ concentration in straw, milled rice, bran and hull, representative samples from each plot was taken at harvesting. The plant samples were digested in di-acid mixture $\left(\mathrm{HNO}_{3}\right.$ and $\mathrm{HClO}_{4}$ in the ratio of 9:4). The potassium content was determined by using flame photometer method and expressed as percentage and $\mathrm{mg} \mathrm{kg}^{-1}$ of dry matter. The potassium uptake was computed by multiplying the potassium concentration with plant biomass and was expressed as potassium uptake in $\mathrm{kg} \mathrm{ha}^{-1}$. For determination of available $\mathrm{K}$ in soil, flame photometric method was used. In this method, $1 \mathrm{~N}$ ammonium acetate solution was used to extract the $\mathrm{K}$ from soil. Reading was taken for soil extract and standard solutions. Standard curve was drawn with the readings for the standard solutions and read the concentrations of the extracts from the standard curve. The value of available $\mathrm{K}$ was expressed in terms of $\mathrm{kg} \mathrm{K} \mathrm{ha}^{-1}$. All the data obtained from the experiment were statistically analyzed using the F-test as per the standard statistical procedure (Gomez and Gomez, 1984) and least significant difference (LSD) values $(p=0.05)$ were used to determine the significance of difference between treatment means.

\section{Results and Discussion}

\subsection{Potassium concentration in rice at different growth stages}

Concentration of $\mathrm{K}$ decreased as crop turns towards maturity with highest concentration at 40 DAS and the lowest in milled rice (Table 1). This decrease in concentration was attributed by dilution effect of increase in dry matter and decrease in K uptake towards crop maturity. Senapati et al. (2009) also mentioned the decrease in $\mathrm{K}$ concentration from maximum tillering stage to panicle initiation stage. Concentration in straw was 14 to 15 times higher than milled rice and 2.5 to 2.7 times higher than hull. Variation in $\mathrm{K}$ concentration among straw and rough rice was also mentioned by Sarkar et al. (2017). Decrease in K concentration was highest during 70 to 100 DAS and the lowest during 40 to 70 DAS. This variation was mainly due to variation in rate of increase in dry matter. Cultivation methods create significant variation in $\mathrm{K}$ concentration at all observations recorded and in all components of rough rice. Among cultivation methods, SRI and PTR remained statistically identical to each other and both found statistically superior to ARS at all observations. This variation might be due to change in the availability of $K$ in soil due to various hydrological regimes among cultivation methods or due to different growth vigour of rice plant due 


\begin{tabular}{|c|c|c|c|c|c|c|c|c|c|c|c|c|c|c|}
\hline \multirow[t]{2}{*}{ Treatment } & \multicolumn{7}{|c|}{ Potassium concentration (\%) } & \multicolumn{7}{|c|}{ Potassium uptake $\left(\mathrm{kg} \mathrm{ha}^{-1}\right)$} \\
\hline & $\begin{array}{l}40 \\
\text { DAS }\end{array}$ & $\begin{array}{c}70 \\
\text { DAS }\end{array}$ & $\begin{array}{l}100 \\
\text { DAS }\end{array}$ & straw & $\begin{array}{c}\text { Milled } \\
\text { rice } \\
\left(\mathrm{mg} \mathrm{kg}^{-1}\right)\end{array}$ & Bran & Hull & $\begin{array}{c}40 \\
\text { DAS }\end{array}$ & $\begin{array}{c}70 \\
\text { DAS }\end{array}$ & $\begin{array}{l}100 \\
\text { DAS }\end{array}$ & straw & $\begin{array}{l}\text { Milled } \\
\text { rice }\end{array}$ & Bran & Hull \\
\hline \multicolumn{15}{|c|}{ Crop cultivation methods } \\
\hline $\begin{array}{l}\text { Puddled } \\
\text { transplant- } \\
\text { ed rice }\end{array}$ & 1.80 & 1.71 & 1.44 & 1.31 & 866.5 & 0.33 & 0.51 & 18.9 & 54.7 & 93.7 & 94.6 & 2.31 & 1.48 & 4.66 \\
\hline $\begin{array}{l}\text { System of } \\
\text { rice inten- } \\
\text { sification }\end{array}$ & 1.81 & 1.72 & 1.45 & 1.32 & 867.4 & 0.33 & 0.52 & 19.0 & 54.6 & 95.3 & 94.9 & 2.33 & 1.51 & 4.62 \\
\hline $\begin{array}{l}\text { Aerobic } \\
\text { rice system }\end{array}$ & 1.69 & 1.60 & 1.31 & 1.20 & 854.3 & 0.27 & 0.44 & 17.5 & 49.9 & 83.7 & 83.2 & 2.14 & 1.17 & 4.07 \\
\hline SEm \pm & 0.013 & 0.01 & 0.01 & 0.01 & 1.31 & 0.00 & 0.01 & 0.11 & 0.29 & 0.55 & 0.43 & 0.01 & 0.04 & 0.04 \\
\hline $\begin{array}{l}\operatorname{LSD}(p= \\
0.05)\end{array}$ & 0.050 & 0.04 & 0.03 & 0.03 & 5.15 & 0.02 & 0.02 & 0.44 & 1.13 & 2.16 & 1.71 & 0.04 & 0.16 & 0.17 \\
\hline \multicolumn{15}{|c|}{ Nutrient management options } \\
\hline $\begin{array}{l}\text { Control } \\
\left(\mathrm{N}_{0} \mathrm{P}_{0} \mathrm{Zn} \mathrm{n}_{0}\right)\end{array}$ & 1.57 & 1.46 & 1.24 & 1.13 & 842.5 & 0.20 & 0.35 & 14.7 & 38.1 & 65.9 & 69.9 & 1.70 & 0.73 & 2.86 \\
\hline $\mathrm{RDN}^{*}$ & 1.80 & 1.72 & 1.45 & 1.31 & 867.4 & 0.33 & 0.52 & 19.1 & 55.5 & 96.1 & 94.6 & 2.35 & 1.51 & 4.73 \\
\hline $\mathrm{RDN}+\mathrm{Zn}^{* *}$ & 1.83 & 1.78 & 1.47 & 1.33 & 871.9 & 0.34 & 0.53 & 19.5 & 59.6 & 100.4 & 99.6 & 2.49 & 1.57 & 4.92 \\
\hline $75 \%$ RDN & 1.75 & 1.60 & 1.33 & 1.24 & 854.9 & 0.29 & 0.46 & 18.3 & 49.0 & 83.5 & 84.3 & 2.09 & 1.30 & 4.16 \\
\hline $\begin{array}{l}75 \% \text { RDN+ } \\
\mathrm{Zn}\end{array}$ & 1.75 & 1.60 & 1.35 & 1.24 & 856.0 & 0.30 & 0.46 & 18.5 & 50.0 & 86.1 & 86.6 & 2.17 & 1.37 & 4.25 \\
\hline $\begin{array}{l}75 \% \text { RDN+ } \\
\text { MI1 }\end{array}$ & 1.78 & 1.71 & 1.43 & 1.30 & 866.3 & 0.33 & 0.51 & 18.7 & 54.6 & 94.2 & 92.8 & 2.32 & 1.46 & 4.67 \\
\hline $\begin{array}{l}75 \% \text { RDN+ } \\
M I 1+Z n\end{array}$ & 1.81 & 1.74 & 1.45 & 1.31 & 868.9 & 0.33 & 0.53 & 19.2 & 57.9 & 98.2 & 97.8 & 2.45 & 1.53 & 4.90 \\
\hline $\begin{array}{l}75 \% \text { RDN+ } \\
\text { MI2 }\end{array}$ & 1.79 & 1.71 & 1.43 & 1.30 & 866.8 & 0.32 & 0.52 & 18.9 & 54.8 & 94.7 & 93.6 & 2.33 & 1.47 & 4.65 \\
\hline $\begin{array}{l}75 \% \text { RDN+ } \\
M I 2+Z n\end{array}$ & 1.82 & 1.74 & 1.46 & 1.33 & 869.8 & 0.33 & 0.53 & 19.3 & 58.2 & 99.1 & 98.9 & 2.46 & 1.55 & 4.92 \\
\hline SEm \pm & 0.033 & 0.03 & 0.02 & 0.02 & 2.68 & 0.01 & 0.01 & 0.30 & 0.75 & 1.23 & 1.00 & 0.02 & 0.06 & 0.12 \\
\hline $\begin{array}{l}\operatorname{LSD}(p= \\
0.05)\end{array}$ & 0.094 & 0.08 & 0.06 & 0.04 & 7.62 & 0.02 & 0.03 & 0.86 & 2.13 & 3.49 & 2.84 & 0.05 & 0.16 & 0.34 \\
\hline Interaction & NS & NS & $\mathrm{s}$ & $\mathrm{s}$ & $\mathrm{S}$ & $\mathrm{S}$ & $\mathrm{s}$ & $\mathrm{s}$ & $\mathrm{s}$ & $\mathrm{S}$ & $\mathrm{S}$ & $\mathrm{s}$ & $\mathrm{s}$ & $\mathrm{s}$ \\
\hline
\end{tabular}

$\mathrm{RDN}^{*}$ : Recommended dose of nutrients $120 \mathrm{~kg} \mathrm{~N}^{-1}$ and $25.8 \mathrm{~kg} \mathrm{P} \mathrm{ha}^{-1} ; \mathrm{Zn}^{* *}$ : Soil applied $5 \mathrm{~kg} \mathrm{Zn} \mathrm{ha}{ }^{-1}$ through Zinc sulphate heptahydrate; MI1: (Anabaena sp. (CR1)+Providencia sp. (PR3) consortia; MI2: Anabaena-Pseudomonas biofilmed formulations; DAS: days after sowing; NS: non-significant; S: Significant

to applied main and sub-plot treatments which was clear from Figure 1 ( $a$ and $b)$. Increase in dry matter production due to application of microbial inoculation (Azospirillium sp. and Phosphotika sp.) was also reported by Longkumer and Singh (2013); while increase in dry matter accumulation due to nitrogen was reported by Xie et al. (2007). Concentration remained unaffected due to sources of $\mathrm{N}$ and $\mathrm{P}$ nutrient and $\mathrm{Zn}$ fertilization at all growth stages and affected significantly due to rate of $\mathrm{N}$ and $\mathrm{P}$ fertilization at all growth stages except at 40 DAS. Application of $100 \%$ RDN stood statistically superior to $75 \%$ RDN and both had significantly higher concentration than control. Increase in concentration in straw due to application 

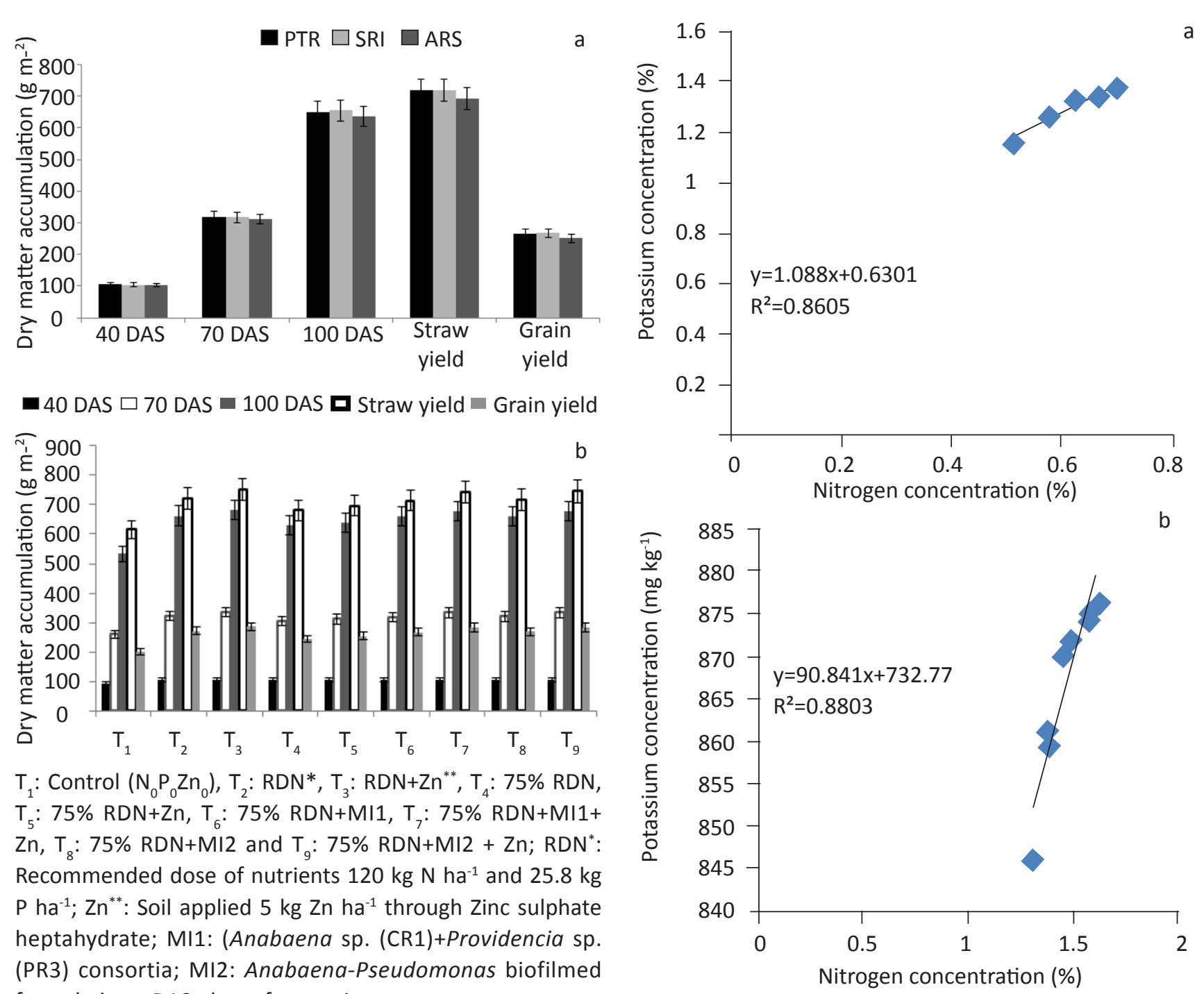

$\mathrm{T}_{1}:$ Control $\left(\mathrm{N}_{0} \mathrm{P}_{0} \mathrm{Zn}_{0}\right), \mathrm{T}_{2}: \mathrm{RDN}^{*}, \mathrm{~T}_{3}: \mathrm{RDN}+\mathrm{Zn}^{* *}, \mathrm{~T}_{4}: 75 \% \mathrm{RDN}$, $\mathrm{T}_{5}: 75 \% \mathrm{RDN}+\mathrm{Zn}, \mathrm{T}_{6}: 75 \% \mathrm{RDN}+\mathrm{MI1}, \mathrm{T}_{7}: 75 \% \mathrm{RDN}+\mathrm{MI} 1+$ $\mathrm{Zn}, \mathrm{T}_{8}: 75 \% \mathrm{RDN}+\mathrm{MI} 2$ and $\mathrm{T}_{9}: 75 \% \mathrm{RDN}+\mathrm{MI} 2+\mathrm{Zn} ; \mathrm{RDN}^{*}$ : Recommended dose of nutrients $120 \mathrm{~kg} \mathrm{~N} \mathrm{ha}^{-1}$ and $25.8 \mathrm{~kg}$

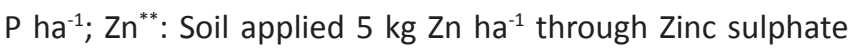
heptahydrate; MI1: (Anabaena sp. (CR1)+Providencia sp. (PR3) consortia; MI2: Anabaena-Pseudomonas biofilmed formulations; DAS: days after sowing

Figure 1: Dry matter accumulation of rice at different growth stages as affected by crop cultivation methods (a) and nutrient management treatments (b) (data averaged over two years)

of $100 \%$ RDN was 0.07 and $0.18 \%$ over $75 \%$ RDN ad control, respectively; while same increase for milled rice was 13 and 25 $\mathrm{mg} \mathrm{kg}^{-1}$ respectively, even though rate of $\mathrm{K}$ application and soil initial available $K$ was same in all treatments. Concentration of $\mathrm{K}$ was positively correlated with $\mathrm{N}$ and $\mathrm{P}$ concentration in straw and milled rice (Figure 2 and 3 ) in our study which showed the positive effect of $\mathrm{N}$ application on $\mathrm{K}$ concentration. Interaction effect of cultivation methods and nutrient management treatments was significant at all observation (except 40 DAS) which indicates that, performance of sup-plot treatments varied in each method of rice cultivation.

\subsection{Potassium uptake in rice at different growth stages}

Uptake of $\mathrm{K}$ increased with growth and the highest $\mathrm{K}$ accumulated in straw and the lowest in bran. This variation was

Figure 2: Correlation of potassium concentration and nitrogen concentration in straw (a) and milled rice (b) during first year of study

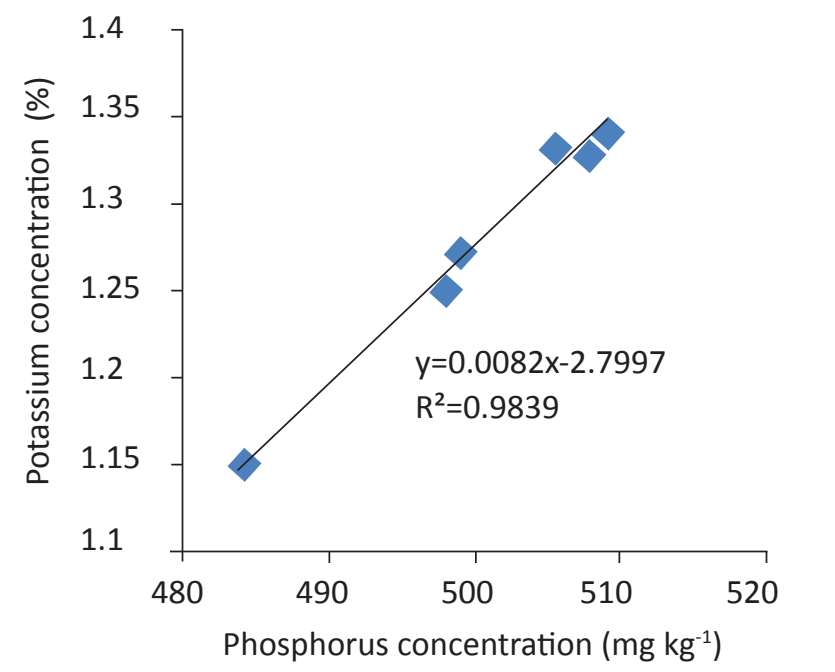
a

Figure 3: Continue... 


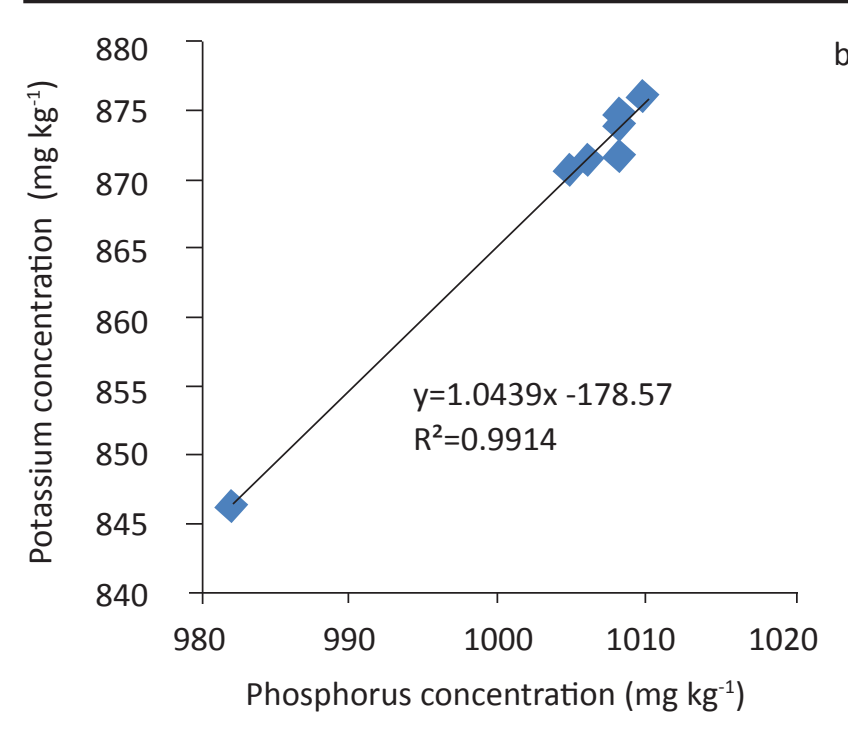

Figure 3: Correlation of potassium concentration and phosphorus concentration in straw (a) and milled rice (b) during first year of study

mainly due to higher concentration and dry matter production of straw than all components of rough rice. Chatterjee and Sanyal (2007) also observed such variation in K distribution among straw and grain of rice. Out of total uptake, 88 to $94 \%$ was accumulated in straw and remaining in rough rice grain (Table 1 ). As most of the $\mathrm{K}$ remained in straw, recycling of $\mathrm{K}$ is possible in arable land effectively by surface straw retention and incorporation (Sarkar et al., 2017). Uptake was remained on par in PTR and SRI and both methods found statistically superior to ARS at all observations during crop growth stages. Total uptake in PTR and SRI was higher by 11-13 and 12-13 $\mathrm{kg} \mathrm{ha}^{-1}$ over ARS. Variation in dry matter production among cultivation methods was the major reason for differences in $\mathrm{K}$ uptake; while a difference in $\mathrm{K}$ concentration was secondary reason. Among nutrient management treatments, RDN + Zn recorded the highest uptake at all observations and remained on par with $75 \% \mathrm{RDN}+\mathrm{MI} 1+\mathrm{Zn}$ and $75 \% \mathrm{RDN}+\mathrm{MI} 2+\mathrm{Zn}$. Variation in rate of nutrients ( $N$ and $P$ ) application showed significant difference in $\mathrm{K}$ uptake at all growth stages except at 40 DAS; while $Z n$ fertilization creates significant difference in uptake at 70 DAS and in straw and milled rice. The application of RDN increased total K uptake by 10-12 and 27-28 kg ha-1 over 75\% RDN and control; while increase in total $\mathrm{K}$ uptake due to $\mathrm{Zn}$ fertilization was $3.9,3.2$ and $5.5 \mathrm{~kg}$ ha $^{-1}$ when Zn was applied with RDN, 75\% RDN+MI1 and 75\% $\mathrm{RDN}+\mathrm{MI}$ 2, respectively in first year and such increase was also occurred during second year too. Application of microbial inoculations increases total $\mathrm{K}$ uptake by 8 to $14 \mathrm{~kg} \mathrm{ha}^{-1}$. The significant variation in $\mathrm{K}$ uptake due to RDN, Zn fertilization and microbial inoculation (MI) even though application rate of $\mathrm{K}$ through this fertilizer and soil initial available $\mathrm{K}$ was same in all treatments. This showed the role of these components of nutrient management in $\mathrm{K}$ nutrition of rice. Improvement in K uptake due to application of optimum dose of nitrogen over suboptimal dose was also reported by El-Hamdi et al. (2010); while increase in $\mathrm{K}$ uptake due to application of recommended dose of $\mathrm{N}$ and $\mathrm{P}$ was reported by Tandon and Sekhon (1988). Interaction effect in case of $\mathrm{K}$ uptake followed similar trend as that of concentration with significance at all observations.

\subsection{Soil available ( $\mathrm{NH}_{4} \mathrm{OAC}$-extractable) $\mathrm{K}$ in soil at different growth stages and potassium balance}

The variation in available soil $\mathrm{K}$ at different observations was mainly due to variation in $\mathrm{K}$ uptake by applied treatments. At 40 DAS, soil $\mathrm{K}$ level was increased by about $32 \mathrm{~kg} \mathrm{ha}^{-1}$ in ARS and $34 \mathrm{~kg} \mathrm{ha}^{-1}$ each in PTR and SRI (Table 2) over initial $\mathrm{K}$ in soil. Among cultivation methods, PTR and SRI remained on par to each other while ARS recorded significantly lower soil $\mathrm{K}$ both at 40 and 70 DAS. Nutrient management treatments did not affect the soil $\mathrm{K}$ level significantly at 40 DAS except control which had significantly higher soil K due to low uptake by rice in control; while at 70 DAS, 75\% RDN (332.6 kg ha-1) and $75 \% \mathrm{RDN}+\mathrm{Zn}\left(331.3 \mathrm{~kg} \mathrm{ha}^{-1}\right)$ recorded significantly higher soil $\mathrm{K}$ content than all other treatments. Soil available K at 100 DAS and at harvest was lower than soil available $K$ at 70 DAS by about 35-40 kg ha ${ }^{-1}$ and 38-45 kg ha-1, respectively. At 100 DAS, ARS recorded the highest soil $\mathrm{K}$ which was significant over PTR, but remained on par with SRI; while at harvest, ARS recorded significantly higher soil $K$ than both PTR and SRI. Among nutrient management treatments, 75\% RDN, $75 \% \mathrm{RDN}+\mathrm{Zn}$ and control recorded significantly higher soil $\mathrm{K}$ at $100 \mathrm{DAS}$ as compared to all other treatments. Lowest soil $\mathrm{K}$ was observed in $\mathrm{RDN}+\mathrm{Zn}$. Superiority of these three treatments was due to lower $K$ uptake and this signifies the close relationship of soil available $\mathrm{K}$ with $\mathrm{K}$ uptake in rice. Mazumdar et al. (2014) also mentioned the close relation of soil available $\mathrm{K}$ and $\mathrm{K}$ uptake in rice.

The soil $\mathrm{K}$ at the start of second rice crop was lower than soil $\mathrm{K}$ present at start of first rice crop by $131 \mathrm{~kg} \mathrm{ha}^{-1}$ in both PTR and SRI and $147 \mathrm{~kg} \mathrm{ha}^{-1}$ in ARS. Soil $\mathrm{K}$ at 40 DAS was increased as compared to initial soil $K$ due to application of $K$ fertilizer as basal dose. At 40 and 70 DAS, both PTR and SRI recorded significantly higher soil $\mathrm{K}$ than ARS. Among nutrient management treatments, control recorded significantly higher soil $\mathrm{K}$ than $75 \% \mathrm{RDN}$ and $75 \% \mathrm{RDN}+\mathrm{Zn}$. These three treatments were statistically superior to all other treatments. Soil K at 100 DAS and at harvest was lower than soil $K$ at 70 DAS by about 16-20 kg ha-1 and 28-35 kg ha-1, respectively. The cultivation methods at 100 DAS and at harvest followed similar trend as that of 70 DAS with both PTR and SRI recorded significantly higher soil $K$ than ARS. Among nutrient management treatments, control recorded the highest soil $\mathrm{K}$ which remained on par with $75 \%$ RDN. Both these two treatments recorded significantly higher soil $\mathrm{K}$ than all other treatments. 
Table 2: Effect of cultivation methods and nutrient management options on soil available potassium (kg ha-1) in rice at different growth stage during 2013 and 2014

\begin{tabular}{|c|c|c|c|c|c|c|c|c|c|c|}
\hline \multirow[t]{3}{*}{ Treatment } & \multicolumn{5}{|c|}{2013} & \multicolumn{5}{|c|}{2014} \\
\hline & Initial & 40 & 70 & 100 & At harvest & Initial & 40 & 70 & 100 & At harvest \\
\hline & & DAS & DAS & DAS & & & DAS & DAS & DAS & \\
\hline \multicolumn{11}{|l|}{ Crop cultivation methods } \\
\hline Puddled transplanted rice & 327 & 361.2 & 326.6 & 287.4 & 283.1 & 195.2 & 242.2 & 223.7 & 203.3 & 188.8 \\
\hline System of rice intensification & 327 & 361.2 & 326.6 & 285.9 & 283.2 & 195.7 & 242.7 & 224.4 & 202.2 & 189.0 \\
\hline Aerobic rice system & 327 & 359.9 & 326.1 & 289.2 & 287.7 & 179.1 & 226.1 & 209.3 & 192.7 & 180.4 \\
\hline SEm \pm & - & 0.12 & 0.34 & 0.63 & 0.46 & 0.45 & 0.49 & 0.61 & 0.85 & 0.92 \\
\hline $\operatorname{LSD}(p=0.05)$ & - & 0.47 & 1.33 & 2.47 & 1.79 & 1.76 & 1.93 & 2.41 & 3.34 & 3.61 \\
\hline \multicolumn{11}{|l|}{ Nutrient management options } \\
\hline Control $\left(\mathrm{N}_{0} \mathrm{P}_{0} \mathrm{Zn}_{0}\right)$ & 327 & 358.2 & 328.4 & 294.5 & 289.4 & 255.6 & 289.8 & 267.1 & 239.5 & 226.2 \\
\hline $\mathrm{RDN}^{*}$ & 327 & 360.9 & 325.7 & 283.5 & 282.2 & 176.6 & 224.6 & 206.5 & 186.8 & 173.9 \\
\hline $\mathrm{RDN}+\mathrm{Zn}^{* *}$ & 327 & 360.4 & 321.1 & 279.4 & 278.3 & 165.8 & 212.6 & 190.2 & 168.7 & 153.4 \\
\hline $75 \%$ RDN & 327 & 361.7 & 332.6 & 298.7 & 294.5 & 208.8 & 260.4 & 250.5 & 237.5 & 225.1 \\
\hline $75 \% \mathrm{RDN}+\mathrm{Zn}$ & 327 & 361.5 & 331.3 & 295.6 & 291.0 & 201.7 & 252.6 & 241.4 & 226.5 & 214.6 \\
\hline $75 \%$ RDN+MI1 & 327 & 361.3 & 326.6 & 286.3 & 283.9 & 183.3 & 232.2 & 215.2 & 196.3 & 184.5 \\
\hline $75 \%$ RDN+MI1+Zn & 327 & 360.8 & 323.0 & 282.3 & 280.7 & 170.4 & 217.7 & 197.0 & 176.0 & 160.6 \\
\hline $75 \%$ RDN+MI2 & 327 & 361.1 & 326.4 & 286.2 & 283.7 & 180.7 & 229.3 & 212.0 & 192.2 & 180.1 \\
\hline $75 \%$ RDN+MI2+Zn & 327 & 360.6 & 323.0 & 280.9 & 278.2 & 166.9 & 213.8 & 192.3 & 171.0 & 156.4 \\
\hline SEm \pm & - & 0.36 & 0.86 & 1.41 & 1.29 & 2.59 & 2.81 & 3.21 & 3.62 & 3.57 \\
\hline $\operatorname{LSD}(p=0.05)$ & - & 1.02 & 2.45 & 4.00 & 3.67 & 7.37 & 8.00 & 9.12 & 10.28 & 10.15 \\
\hline Interaction & - & $\mathrm{S}$ & $\mathrm{S}$ & NS & NS & NS & NS & NS & NS & NS \\
\hline
\end{tabular}

RDN*: Recommended dose of nutrients $120 \mathrm{~kg} \mathrm{~N} \mathrm{ha}^{-1}$ and $25.8 \mathrm{~kg} \mathrm{P} \mathrm{ha-1;} \mathrm{Zn**:} \mathrm{Soil} \mathrm{applied} 5$ kg Zn haha-1 through Zinc sulphate heptahydrate; MI1: (Anabaena sp. (CR1)+Providencia sp. (PR3) consortia; MI2: Anabaena-Pseudomonas biofilmed formulations; DAS: days after sowing; NS: non-significant; S: Significant

Lowest soil $\mathrm{K}$ was observed in RDN+Zn both at 100 DAS and at harvest and same treatment recorded the highest $\mathrm{K}$ uptake. The significant role of soil inherent available $\mathrm{K}$ over $\mathrm{K}$ applied through fertilizer in meeting $\mathrm{K}$ need of rice was justified from consistent decrease in soil available $K$ status even after application of recommended dose of $\mathrm{K}$. This consistent decreased in soil available $\mathrm{K}$ responsible for negative balance of $\mathrm{K}$ as reported by Sharma and Sharma (2002) and Panaullah et al. (2006) also mentioned the negative balance of soil available K. Singh et al. (2004) reported the depletion of soil $K$ in rice-wheat cropping system even when optimum level of $K$ was applied and on similar line, Tandon (2007) showed negative balance of $\mathrm{K}$ in most of the states in India.

The soil available and total $\mathrm{K}$ at initial stage present in soil did not differ among cultivation methods in the first year due to due to same rate of $\mathrm{K}$ application; while both were found significantly higher in both PTR and SRI than ARS in the second year (Table 3 ). In second year, $\mathrm{K}$ uptake in first season rice crop and wheat planted after first rice crop was main factor responsible for variation in available $\mathrm{K}$ status in soil. The balance and actual $\mathrm{K}$ present in soil at rice harvest was significantly higher in ARS than both PTR and SRI in the first year. One possible reason for this difference was significantly lower total K uptake in ARS than PTR and SRI. In second year, the balance and actual soil $\mathrm{K}$ was found significantly higher in both PTR and SRI over ARS. Variation between actual $\mathrm{K}$ present in the soil and calculated balance was 4-13 and 39-43 kg ha-1 in the first and the second year, respectively. The available and total $\mathrm{K}$ was found higher in control in both years which was found statistically superior to $75 \%$ RDN and $75 \% \mathrm{RDN}+\mathrm{Zn}$. These three treatments were superior to all other treatments which were mainly due to lower uptake. Balance and actual $\mathrm{K}$ present in soil at harvest in both years also found higher in above-mentioned three treatments and this again showed the relationship of $\mathrm{K}$ uptake with available $\mathrm{K}\left(\mathrm{NH}_{4} \mathrm{OAC}\right.$-extractable) in soil. 


\begin{tabular}{|c|c|c|c|c|c|c|c|c|c|c|c|c|}
\hline \multirow[t]{2}{*}{ Treatment } & \multicolumn{2}{|c|}{$\begin{array}{l}\text { Available soil } \\
\text { potassium } \\
\left(\mathrm{kg} \mathrm{ha}^{-1}\right)\end{array}$} & \multicolumn{2}{|c|}{$\begin{array}{c}\text { Potassium ap- } \\
\text { plied through } \\
\text { fertilizer } \\
\left(\mathrm{kg} \mathrm{ha}^{-1}\right) \\
\end{array}$} & \multicolumn{2}{|c|}{$\begin{array}{c}\text { Total potas- } \\
\text { sium present } \\
\text { in soil }\left(\mathrm{kg} \mathrm{ha}^{-1}\right)\end{array}$} & \multicolumn{2}{|c|}{$\begin{array}{l}\text { Total uptake } \\
\text { of potassium } \\
\left(\mathrm{kg} \mathrm{ha}^{-1}\right)\end{array}$} & \multicolumn{2}{|c|}{$\begin{array}{l}\text { Balance } \\
\left(\mathrm{kg} \mathrm{ha}^{-1}\right)\end{array}$} & \multicolumn{2}{|c|}{$\begin{array}{c}\text { Actual potas- } \\
\text { sium present in } \\
\text { soil after har- } \\
\text { vest }\left(\mathrm{kg} \mathrm{ha}^{-1}\right) \\
\end{array}$} \\
\hline & 2013 & 2014 & 2013 & 2014 & 2013 & 2014 & 2013 & 2014 & 2013 & 2014 & 2013 & 2014 \\
\hline \multicolumn{13}{|c|}{ Crop cultivation methods } \\
\hline $\begin{array}{l}\text { Puddled transplanted } \\
\text { rice }\end{array}$ & 327 & 195.2 & 49.8 & 49.8 & 376.8 & 245.0 & 106.8 & 99.4 & 270.0 & 145.6 & 283.1 & 188.8 \\
\hline $\begin{array}{l}\text { System of rice } \\
\text { intensification }\end{array}$ & 327 & 195.7 & 49.8 & 49.8 & 376.8 & 245.5 & 106.7 & 99.9 & 270.1 & 145.6 & 283.2 & 189.0 \\
\hline Aerobic rice system & 327 & 179.1 & 49.8 & 49.8 & 376.8 & 228.9 & 93.5 & 87.7 & 283.3 & 141.2 & 287.7 & 180.4 \\
\hline SEm \pm & - & 0.45 & - & - & 0.00 & 0.45 & 0.46 & 0.58 & 0.46 & 0.99 & 0.46 & 0.92 \\
\hline $\operatorname{LSD}(p=0.05)$ & - & 1.76 & - & - & 0.00 & 1.76 & 1.79 & 2.29 & 1.79 & 3.89 & 1.79 & 3.61 \\
\hline \multicolumn{13}{|c|}{ Nutrient management options } \\
\hline Control $\left(\mathrm{N}_{0} \mathrm{P}_{0} \mathrm{Zn}_{0}\right)$ & 327 & 255.6 & 49.8 & 49.8 & 376.8 & 305.4 & 78.7 & 71.6 & 298.1 & 233.8 & 289.4 & 226.2 \\
\hline $\mathrm{RDN}^{*}$ & 327 & 176.6 & 49.8 & 49.8 & 376.8 & 226.4 & 107.1 & 99.3 & 269.7 & 127.1 & 282.2 & 173.9 \\
\hline $\mathrm{RDN}+\mathrm{Zn}^{* *}$ & 327 & 165.8 & 49.8 & 49.8 & 376.8 & 215.6 & 111.0 & 106.1 & 265.8 & 109.5 & 278.3 & 153.4 \\
\hline $75 \%$ RDN & 327 & 208.8 & 49.8 & 49.8 & 376.8 & 258.6 & 94.9 & 88.8 & 281.9 & 169.8 & 294.5 & 225.1 \\
\hline $75 \% \mathrm{RDN}+\mathrm{Zn}$ & 327 & 201.7 & 49.8 & 49.8 & 376.8 & 251.5 & 98.3 & 90.4 & 278.5 & 161.1 & 291.0 & 214.6 \\
\hline $75 \%$ RDN+MI1 & 327 & 183.3 & 49.8 & 49.8 & 376.8 & 233.1 & 105.4 & 97.1 & 271.4 & 136.0 & 283.9 & 184.5 \\
\hline 75\% RDN+MI1+Zn & 327 & 170.4 & 49.8 & 49.8 & 376.8 & 220.2 & 108.6 & 104.7 & 268.2 & 115.5 & 280.7 & 160.6 \\
\hline 75\% RDN+MI2 & 327 & 180.7 & 49.8 & 49.8 & 376.8 & 230.5 & 105.7 & 98.3 & 271.1 & 132.2 & 283.7 & 180.1 \\
\hline $75 \%$ RDN+MI2+Zn & 327 & 166.9 & 49.8 & 49.8 & 376.8 & 216.7 & 111.2 & 104.5 & 265.6 & 112.2 & 278.2 & 156.4 \\
\hline SEm \pm & - & 2.59 & - & - & 0.00 & 2.59 & 1.29 & 1.12 & 1.29 & 3.31 & 1.29 & 3.57 \\
\hline $\operatorname{LSD}(p=0.05)$ & - & 7.37 & - & - & 0.00 & 7.37 & 3.67 & 3.20 & 3.67 & 9.42 & 3.67 & 10.15 \\
\hline Interaction & - & NS & - & - & NS & $\mathrm{s}$ & $\mathrm{s}$ & $\mathrm{s}$ & $\mathrm{s}$ & NS & NS & NS \\
\hline
\end{tabular}

RDN $^{*}$ : Recommended dose of nutrients $120 \mathrm{~kg} \mathrm{~N} \mathrm{ha}^{-1}$ and $25.8 \mathrm{~kg} \mathrm{P} \mathrm{ha}^{-1} ; \mathrm{Zn}^{* *}$ : Soil applied $5 \mathrm{~kg} \mathrm{Zn} \mathrm{ha}^{-1}$ through Zinc sulphate heptahydrate; MI1: (Anabaena sp. (CR1)+Providencia sp. (PR3) consortia; MI2: Anabaena-Pseudomonas biofilmed formulations; DAS: days after sowing; NS: non-significant; S: Significant

\section{Conclusion}

Potassium concentration and uptake by rice was not only depend on $\mathrm{K}$ fertilization but also on application rates and sources of $\mathrm{N}$ and $\mathrm{P}$ fertilizers; $\mathrm{Zn}$ fertilization and microbial inoculation had significant influence on concentration and uptake of $\mathrm{K}$. The calculated balance as well as actual available $\mathrm{K}$ in soil showed negative trend over initial soil available $\mathrm{K}$ indicating need of $\mathrm{K}$ fertilization and consideration for revision of dose for $\mathrm{K}$ fertilization in rice.

\section{Acknowledgement}

The authors duly acknowledge to ICAR-Indian Agricultural Research Institute, New Delhi (India) for providing financial support. Our sincere thanks are also to Division of Agronomy, ICAR-Indian Agricultural Research Institute, New Delhi (India) for providing facilities required for this experiment.

\section{References}

Anonymous, 2017. Annual review of fertilizer production and consumption 2016-17, executive summary, Indian Journal of Fertilizers, October 2017, 97-99. Available from: http://www.faidelhi.org/general/Executive\%20 summary.pdf. Assessed on 29 th June, 2017.

Chatterjee, S., Sanyal, S.K., 2007. Site-specific potassium management for rice grown in selected alluvial soils of west Bengal. Better Crops India, 22-25.

El-Hamdi, Kh.H., Ghanem, S.A., Hashem, I.M., 2010. Availability and uptake of nitrogen and potassium as affected by inorganic fertilizers in flooded rice soils. Journal of Soil Science and Agricultural Engineering Mansoura University 1(5), 433-451.

FAI, 2016. Fertilizer statistics, the fertilizer association of India, New Delhi (59 ${ }^{\text {th }}$ Eds.). 
Gomez, K.A., Gomez, A.A., 1984. Statistical procedures for agricultural research $\left(2^{\text {nd }}\right.$ ed). John Wiley and Sons, New York.

Gurav, P.P., Ray, S.K., Choudhari, P.L., Biswas, A.K., Shirale, A.O., 2018. A review on soil potassium scenario in vertisols of India. Open Access Journal of Science 2(1), 89-90. DOI: 10.15406/oajs.2018.02.00051.

Hanway, J.J., Heidel, H., 1952. Soil analysis methods as used in lowa State College Soil Testing Laboratory. Bulletin 57, lowa State College of Agriculture, lowa, USA, 131.

Lindsay, W.L., Norvell, W.A., 1978. Development of DTPA soil test for zinc, iron, manganese and copper. Soil Science Society of America Journal 42, 421-428.

Longkumer, L.T., Singh, P.L., 2013. Response of rice (Oryza sativa L.) to sowing dates, nutrient and weed management. International Journal of Bio-resource and Stress Management 4(4), 523-528

Muzumdar, S.P., Kundu, D.K., Ghosh, D., Saha, A.R., Majumdar, B., Ghorai, A.K., 2014. Effect of long-term application of inorganic fertilizers and organic manure on yield, potassium uptake and distribution of potassium fractions in the new Gangetic alluvial soil under jute-rice-wheat cropping system. International Journal of Agriculture and Food Science Technology 5(4), 297-306.

Olsen, R., Cole, C.V., Watanabe, F.S., Dean, L.A., 1954. Estimation of available phosphorus in soils by extraction with sodium bicarbonate. Circular-939 United States Department of Agriculture, Washington DC, USA.

Panaullah, G.M., Timsina, J., Saleque, M.A., Ishaque, M., Pathan, A.B.M.B.U., Connor, D.J., Saha, P.K., Quayyum, M.A., Humphreys, E., Meisner, C.A., 2006. Nutrient uptake and apparent balances for rice-wheat sequences. III. Potassium. Journal of Plant Nutrition 29, 173-187.

Prasad, R., 2012. Fertilizers and manures. Current Science 102(6), 894-898.

Sarkar, Md.I.U., Islam, Md.N., Jahan, A., Islam, A., Biswas, J.C., 2017. Rice straw as a source of potassium for wetland rice cultivation. Geology Ecology and Landscapes 1(3), 184-189.

Senapati, H.K., Dash, A.K., Santra, G.H., Mohanty, B., 2009. Potassium nutrition of rice as influenced by long-term use of fertilizers in Inceptisol. An Asian Journal of Soil Science 4(1), 149-153.

Sharma, S.K., Sharma, S.N., 2002. Balance sheet of nitrogen, phosphorus and potassium under different rice (Oryza sativa L.)-based cropping systems. Indian Journal of Agronomy 47(1), 6-11.

Shivay, Y.S., Prasad, R., Singh R.K., Pal, M., 2015. Relative efficiency of zinc-coated urea and soil and foliar application of zinc sulphate on yield, nitrogen, phosphorus, potassium, zinc and iron biofortification in grains and uptake by basmati rice (Oryza sativa L.). Journal of Agricultural Science 7(2), 161-173.

Singh, A., Shivay, Y.S., 2014. Enhancement of growth parameters and productivity of Basmati rice through summer green manuring and zinc fertilization. International Journal of Bio-resource and Stress Management 5(4), 486-494.

Singh, B., Singh, Y.V., Imas, P., Chang, X.J., 2004. Potassium nutrition of rice-wheat cropping system. Advances in Agronomy 81, 203-259.

Subbiah, B.V., Asija, G.L., 1956. A rapid procedure for the estimation of available nitrogen in soils. Current Science 25, 259-260.

Syed, T., Anwar, B.M., Ashaq, H., Ganai Manzoor, A., Teli, N.A., 2016. Effect of levels and sources of zinc on growth, yield and economics of rice (Oryza sativa) under temperate conditions. Indian Journal of Agronomy 61(2), 186-190.

Tandon, H.L.S., 2007. Soil nutrient balance sheets in India: Importance, status, issues, and concerns. Better Crops, India, 15-19.

Tandon, H.L.S., 2013. Nutrient in soils, plants, waters, fertilizers and organic manures. In: Methods of analysis of soils, plants, waters, fertilizers and organic manures (Tandon, H.L.S., Edn.). Fertilizer Development and Consultation Organization, New Delhi. India, 204+xii.

Tandon, H.L.S., Sakhon, G.S., 1988. Potassium research and agricultural production in India. Fertilizer Development and Consultation Organization, New Delhi, 144.

Walkley, A.J., Black, I.A., 1934. An examination of the Degtjareff method for determination of soil organic matter and a proposed modification of the chromic acid titration method. Soil Science 37, 29-38.

Xie, W.X., Wang, G.H., Zhang, Q., Guo, H., 2007. Effect of nitrogen fertilizer strategies on nitrogen use efficiency in physiology, recovery and agronomy and redistribution of dry matter accumulation and nitrogen accumulation in two rice cultivars in Zhejiang, China. Journal of Zhejiang University Science B 8(3), 208-216.

Yadav, R.L., Singh R.S., Prasad, K., Dwivedi, B.S., Batta, R.K., Singh, A.K., Patil, N.G., Chaudhary, S.K., 2000. Management of irrigated ecosystem. In: Natural resource management for agricultural production in India (Yadav, J.S.P., Singh, G.B., Eds.) Indian society of Soil science, New Delhi, India, 775-870.

Zhang, H., Xu, M., Shi, X., Li, Z., Huang, Q., Wang, X., 2010. Rice yield, potassium uptake and apparent banance under long-term fertilization in rice-based cropping systems in southern China. Nutrient Cycling in Agroecosystems 88(3), 341-349. 